\title{
Involvement of Galectin-1 Tumor Microenvironment in Radiosensitivity
}

\author{
YI-FAN CHEN ${ }^{1 *}$, CHUNG-CHI WANG ${ }^{1 *}$, CHIEH-YING HSU ${ }^{1}$ and ENG-YEN HUANG ${ }^{1,2}$ \\ ${ }^{1}$ Department of Radiation Oncology, Kaohsiung Chang Gung Memorial Hospital, \\ Chang Gung University College of Medicine, Kaohsiung, Taiwan, R.O.C.; \\ ${ }^{2}$ School of Traditional Chinese Medicine, Chang Gung University College of Medicine, Taoyuan, Taiwan, R.O.C.
}

\begin{abstract}
Background/Aim: The mechanisms of galectin-1 in radioresistance may not only involve intracellular but also extracellular effects because galectin-1 can be secreted into the extracellular matrix. We, therefore, aimed to investigate the role of the galectin-1 tumor microenvironment on radiosensitivity in a murine tumor model. Materials and Methods: Wild-type or stable galectin-1-down-regulated cancer cells (melanoma (B16F10) and lung cancer (LLC1)) were injected (subcutaneous injection) into wild-type or knockout (galectin-1, B cells, and T cells) mice that were subject to 0 or 8 Gy irradiation. Results: Galectin-1-downregulated B16F10 cells showed increased radiosensitivity when injected into galectin-1 knockout mice. Interestingly, radioresistance of wild-type LCC1 tumors was noted when injected into galectin-1 and B cell knockout mice. However, radiosensitization was observed in $T$ cell knockout mice with wild-type LCC1 cells. Conclusion: The role of endogenous galectin-1 in radioresistance exists in cases without extracellular galectin-1. Extracellular galectin-1 requires endogenous galectin-1 to radiosensitize tumors in mice.
\end{abstract}

The role of galectin-1 in tumor progression $(1,2)$ and sensitivity to radiotherapy/chemotherapy is well studied (3-5). The correlation between galectin- 1 and immune cells does not only apply in T cells. Galectin-1 can affect dendritic cells and lead to immune enhancement (6) or suppression (7). If

This article is freely accessible online.

*These Authors contributed equally to this study.

Correspondence to: Dr. Eng-Yen Huang, Department of Radiation Oncology, Kaohsiung Chang Gung Memorial Hospital, Chang Gung University College of Medicine, No. 129, Dapi Rd., Niaosong Dist., Kaohsiung City 83301, Taiwan, R.O.C. Tel: +886 77317123 ext.7000, Fax: +886 77322813, e-mail: huangengyen@gmail.com

Key Words: Galectin-1, tumor microenvironment, radiosensitivity. galectin-1 affects natural killer (NK) cells, it can cause tumors to shrink to a very small size and can lead to long-term survival (8). Affected Treg cells also have immunosuppressive functions (9). An increasing number of studies indicate that hypoxia can increase tumor galectin-1 expression (10) and attract macrophages to hypoxic tumor regions (11-13). Therefore, it is likely that tumor galectin-1 will not only inhibit anticancer $\mathrm{T}$ and $\mathrm{NK}$ cells around the tumor, but also attract macrophages to the tumor. We investigated the role of the galectin-1 tumor microenvironment on radiosensitivity.

\section{Materials and Methods}

Cell lines and culture. Cancer cells were purchased from Building and Construction Resource Center (BCRC, Hsinchu, Taiwan, ROC). LLC1 lung cancer cells (BCRC No. 60050) and B16F10 melanoma cells (BCRC No. 60031) were maintained with specified medium containing 10\% fetal bovine serum (FBS) (Gibco Life Technologies), penicillin (100 U/ml) (Gibco Life Technologies), and streptomycin $(100 \mathrm{mg} / \mathrm{ml})$ (Gibco Life Technologies) in a humidified tissue culture incubator at $37^{\circ} \mathrm{C}$ in a $5 \% \mathrm{CO}_{2}$ atmosphere.

Stable knockdown of galectin-1 in cell lines. All recombinant lentiviruses were purchased from the RNAi Core Facility (Academia Sinica, Taiwan, ROC). Lentiviral infection (MOI 0.3) was performed according to the manufacturer's protocol. For viral infections, cancer cells were plated and had reached approximately $50 \%$ confluency after $24 \mathrm{~h}$. The entire amount of viral stock and polybrene $(8 \mu \mathrm{g} / \mathrm{ml})$ in growth medium was added directly onto target cells and incubated at $37^{\circ} \mathrm{C}$ in $5 \% \quad \mathrm{CO}_{2}$. At $24 \mathrm{~h}$ post infection, the medium was replaced with fresh medium supplemented with $10 \%$ FBS. Lentivirus-transduced cells were selected in media containing $0.2-2 \mu \mathrm{g} / \mathrm{ml}$ puromycin.

Irradiation of cancer cells and clonogenic assay. Subconfluent cancer cells in $25 \mathrm{~T}$ flasks were irradiated using a 6-MV linear accelerator (Varain Inc., Palo Alto, CA, USA). Cells were plated in six-well plates immediately following $0,2,4,6$, or 8 Gy irradiation. At 1 to 2 weeks following irradiation, glutaraldehyde $(6.0 \% \mathrm{v} / \mathrm{v})$ was used for fixation, and crystal violet $(0.5 \% \mathrm{w} / \mathrm{v})$ was added to stain the colonies. Cells were counted by a stereomicroscope. When 50 or more cells in a colony were counted, the colony was defined as surviving. According 
A

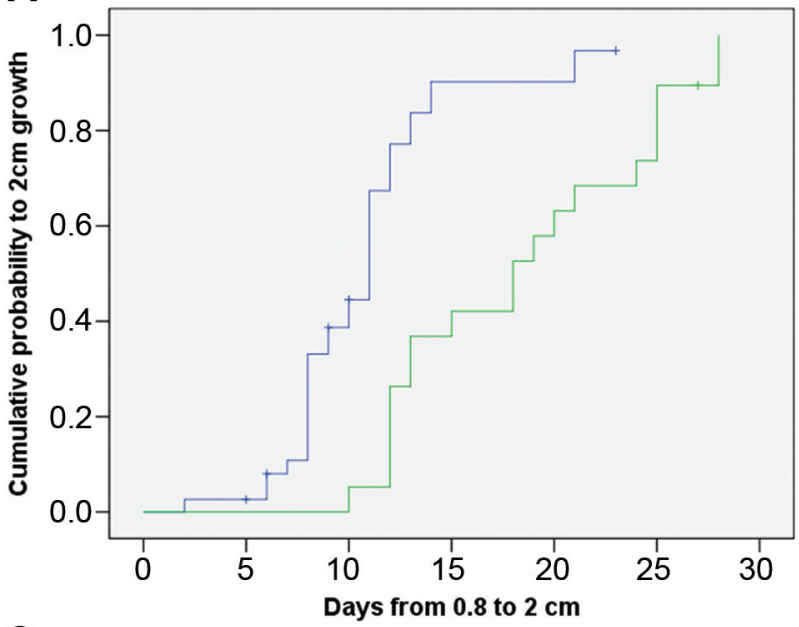

C

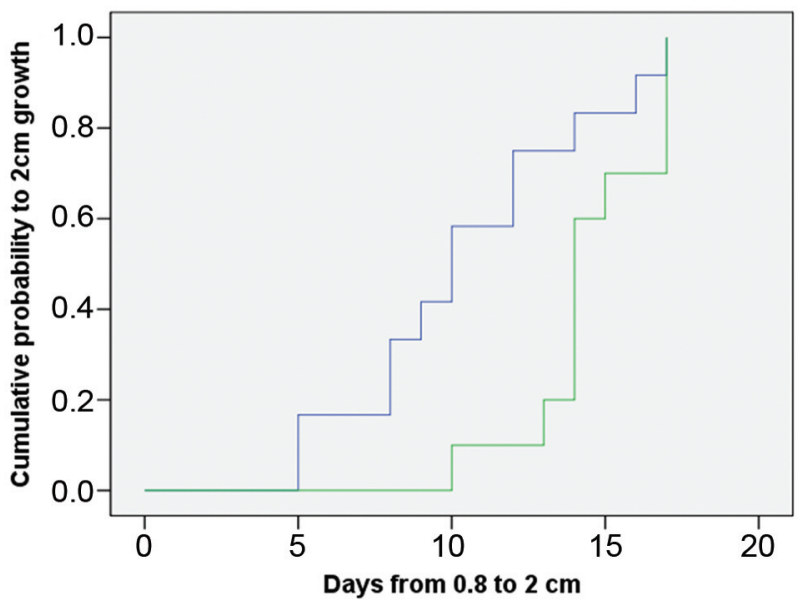

B

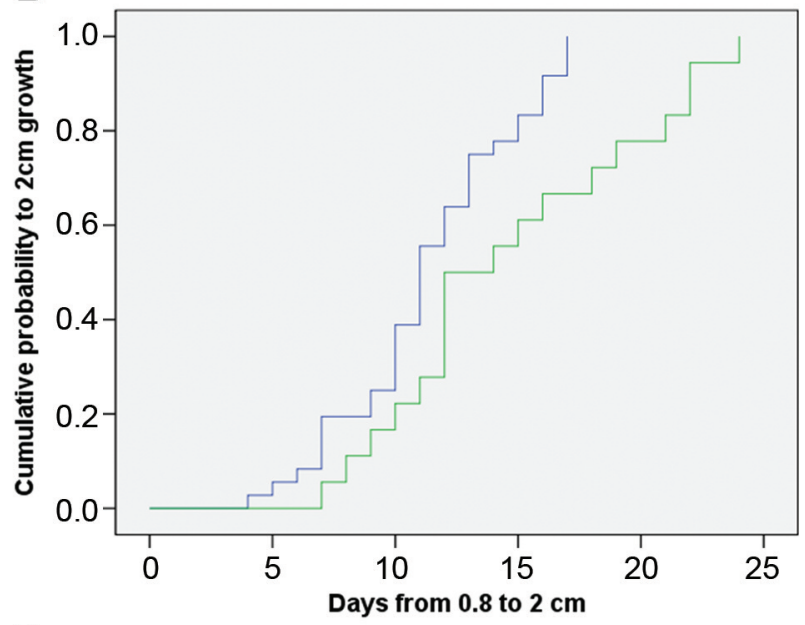

D

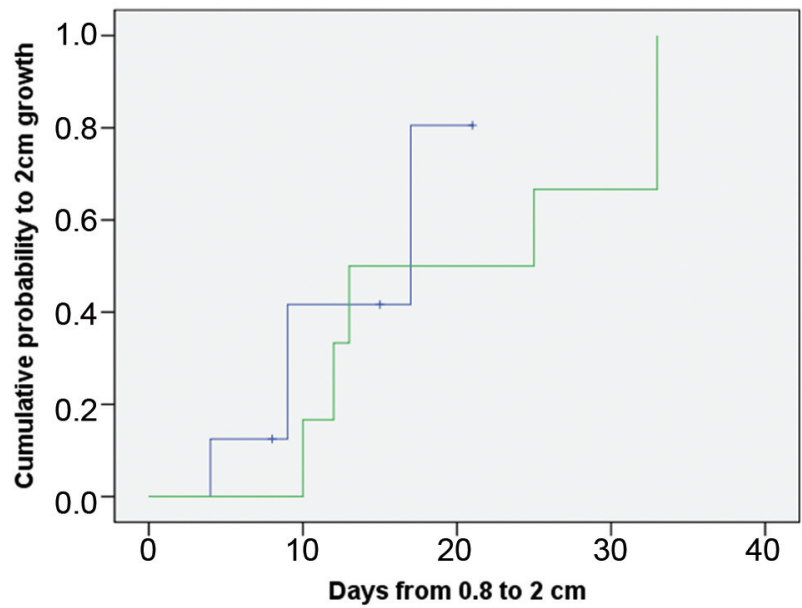

Figure 1. Effects of irradiation on LLC1 tumor growth to $2 \mathrm{~cm}$. Radiation delayed the growth of wild-type tumors to $2 \mathrm{~cm}$ in size in both wild-type $(p<0.001)(A)$ and galectin-1 knockout $(p=0.006)(B)$ mice. Radiation delayed the growth of knockdown tumors to $2 \mathrm{~cm}$ in size in galectin-1 knockout $(p=0.026)(C)$, but not wild-type $(p=0.424)(D)$ mice. Green color represents 8 Gy irradiation.

to the plating efficiency (PE), normalization to 0 Gy in each condition was performed. The surviving fraction was calculated by the number of colonies/(number of cells plated $\times \mathrm{PE}$ ). The survival curve was drawn according to the survival rate $(\log )$ and dose.

Whole-cell protein extract and Western blotting. Cells were lysed in RIPA buffer with $1 \mathrm{mM}$ PMSF, $8.5 \mu \mathrm{g} / \mathrm{ml}$ aprotinin, $2 \mu \mathrm{g} / \mathrm{ml}$ leupeptin, $1 \times$ Roche complete miniprotease inhibitor cocktail, and $1 \times$ Pierce phosphatase inhibitor cocktail following a standard protocol. Protein extracts $(50 \mu \mathrm{g})$ of cells were heated at $94^{\circ} \mathrm{C}$ for $3 \mathrm{~min}$, resolved by $10 \%$ SDS-PAGE, and electrotransferred to PVDF membranes using semidry transfer. The membranes were blocked and then incubated with primary galectin-1 (H-45) antibody (Santa Cruz, CA, USA) followed by a horseradish peroxidaseconjugated secondary antibody (Santa Cruz, CA, USA). The blots were developed with a chemiluminescent HRP substrate (Immobilon ${ }^{\mathrm{TM}}$ Western, Millipore) for $1 \mathrm{~min}$ and then transferred to film (Amersham Hyperfilm ${ }^{\mathrm{TM}} \mathrm{MP}$ ).
Knockout mice preparation. Galectin-1 (B6.Cg-Lgals1 tm1Rob/J, No. 006337), B cell (B6.129S2-Ighm ${ }^{\mathrm{tm} 1 \mathrm{Cgn} / J}$, No. 002288), and T cell (B6.CgFoxn1 nu/J, No. 000819) knockout mice (Jackson Laboratory) and the same strain of wild-type mice were purchased. Mice were imported by BioLASCO Taiwan Co., Ltd and then transferred to the National Animal Center for breeding, which was successful.

Animal studies. Experimental protocols for laboratory animals were approved by the IACUC of Kaohsiung Chang Gung Memorial Hospital (No. 2015031702). The LLC1 and B16F10 cancer cell lines were used in the above experiment, and $2 \times 10^{6}$ cancer cells were injected into the back of the hind legs of mice. The tumor was irradiated $(0$ or $8 \mathrm{~Gy})$ when the tumor reached $0.8 \mathrm{~cm}$. Then, the time required for the tumor to reach two centimeters was calculated. The tumor sizes were measured twice weekly, and the tumor volume was calculated using the following formula: width ${ }^{2} \times$ length $\times 0.52$ $\left(\mathrm{mm}^{3}\right)$. Mice were humanely euthanized when the tumor was $2 \mathrm{~cm}$ in size. The tumor was assessed using IHC analysis. The Kaplan- 
A

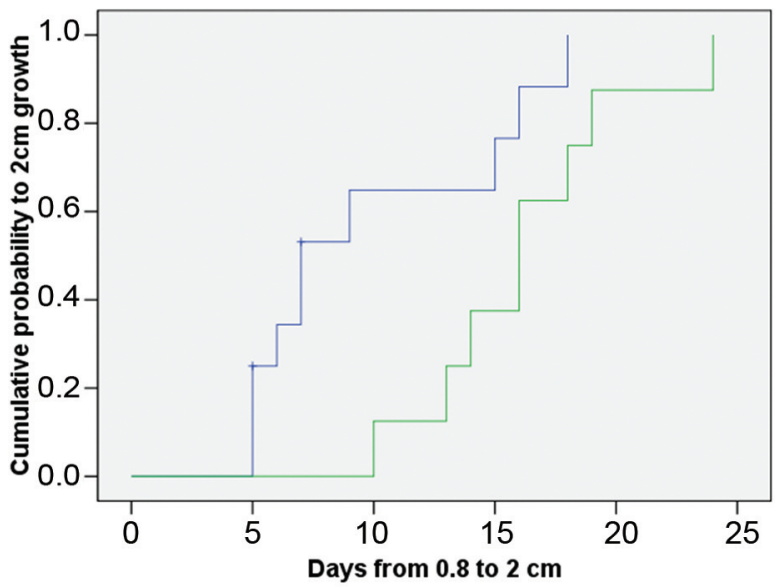

C

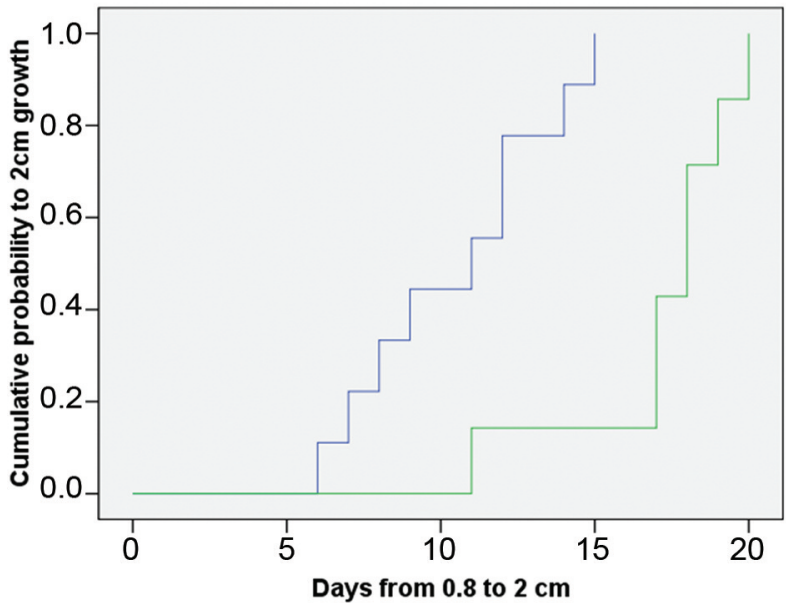

B

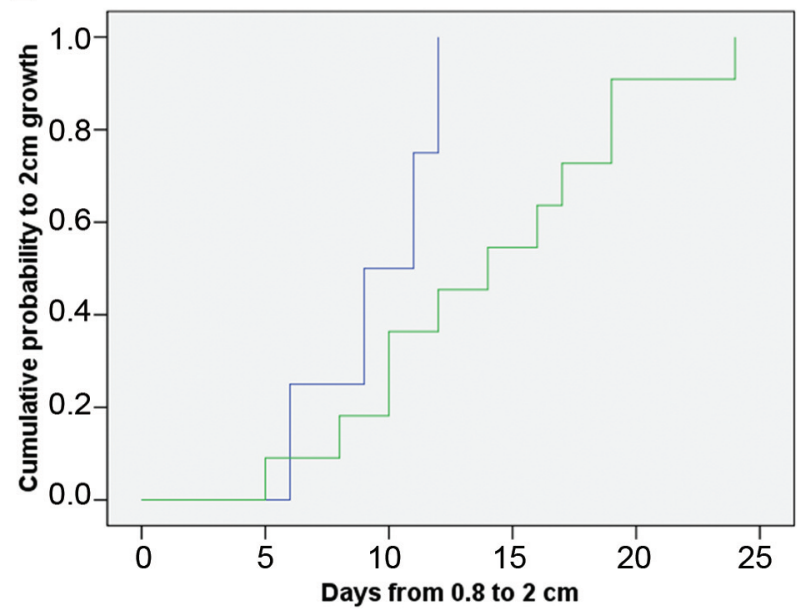

D

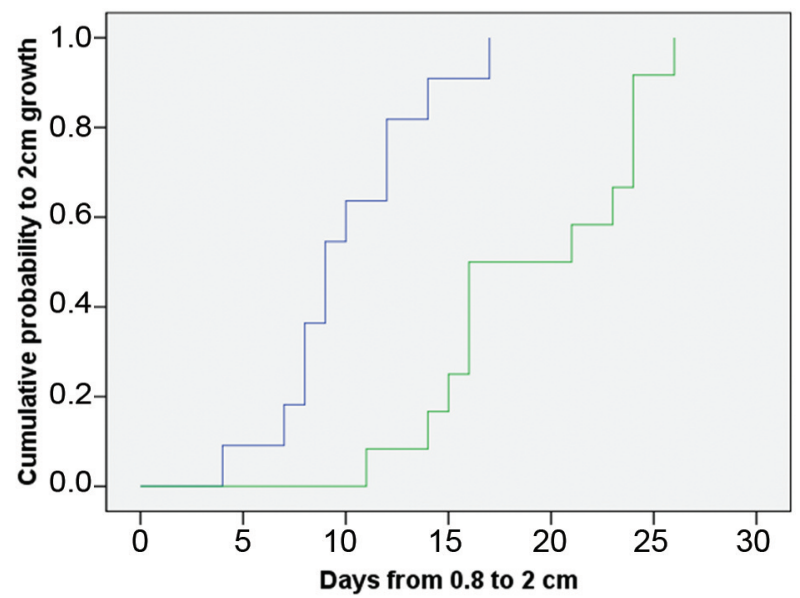

Figure 2. Effects of irradiation on B16-F10 tumor growth to $2 \mathrm{~cm}$. Radiation delayed the growth of wild-type tumors to $2 \mathrm{~cm}$ in size in wild-type $(p=0.031)(A)$ but not galectin-1 knockout $(p=0.071)(B)$ mice. Radiation delayed the growth of knockdown tumors to $2 \mathrm{~cm}$ in size in both galectin1 knockout $(p=0.001)(C)$ and wild-type $(p=0.001)(D)$ mice. Green color represents 8 Gy irradiation.

Meier method was used to calculate the actuarial rate of the tumor to two centimeters after irradiation.

Immunohistochemistry (IHC). Tissues were fixed in $10 \%$ buffered formalin and embedded in paraffin, and sections ( $3 \mathrm{~mm}$ thick) were used for hematoxylin and eosin staining and immunohistochemistry (IHC). To block endogenous peroxidase activity, the sections were incubated with $3 \%$ hydrogen peroxide for $10 \mathrm{~min}$. Slides were pressure cooked in antigen retrieval buffer (Leica, Epitope Retrieval Solution) for $20 \mathrm{~min}$. Subsequently, slides were washed and incubated with block buffer (Thermo Fisher Scientific) to suppress non-specific binding and then incubated with primary antibody directed against F4/80 (MCA497G, BioRad) at dilutions of 1:100 in antibody diluent reagent solution (Invitrogen) overnight at $4^{\circ} \mathrm{C}$. After washing, the sections were incubated with a horseradish peroxidase (HRP)-conjugated anti-rat universal immune-peroxidase polymer (N-Histofine, Nichirei Biosciences Inc., Japan) for $30 \mathrm{~min}$ and visualized with 3,3'-diaminobenzidine (DAB). As a negative control, another set of sections stained without primary antibodies was subjected to incubation with secondary antibodies, DAB treatment, and hematoxylin staining.

\section{Results}

Irradiation effects. First, we confirmed that 8 Gy radiation delays the time required for tumor growth to $2 \mathrm{~cm}$. Wild-type LLC1 cells were transplanted into wild-type and galectin-1 knockout mice. Radiation delayed the growth of tumors to 2 $\mathrm{cm}$ in size in both wild-type $(p<0.001)$ (Figure 1A) and galectin-1 knockout ( $p=0.006$ ) (Figure 1B) mice. The growth delay time is less evident in galectin-1 knockout mice. In LLC1 cells with galectin-1 knockdown, a difference was noted in galectin-1 knockout ( $p=0.026$ ) (Figure 1C) but not wildtype $(p=0.424)$ (Figure 1D) mice. Wild-type B16-F10 cells 
A

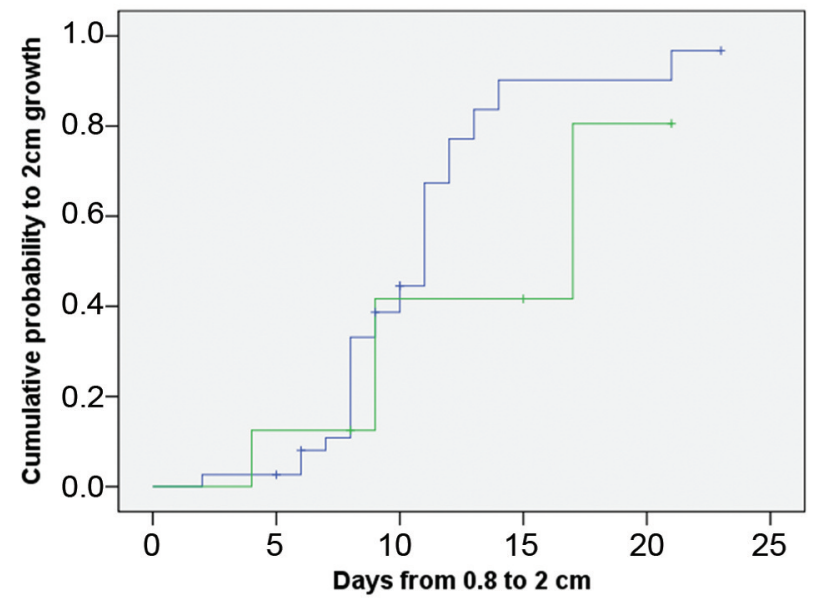

C

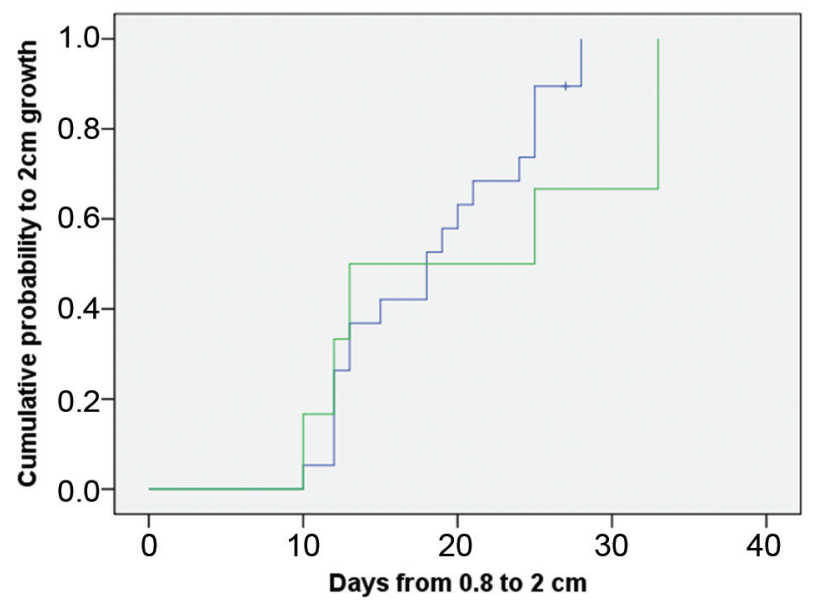

B

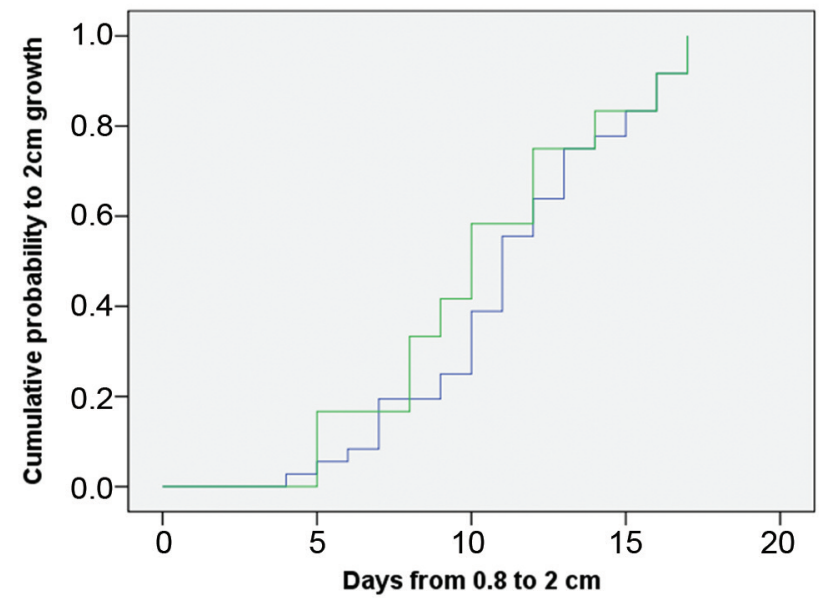

D

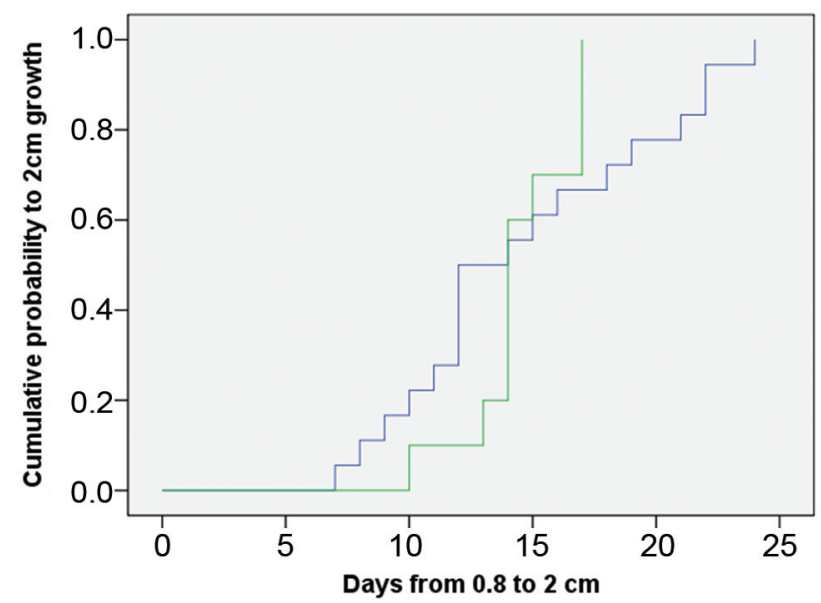

Figure 3. Effects of endogenous galectin-1 on LLC1 tumor growth to $2 \mathrm{~cm}$. No role of endogenous galectin-1 in wild-type ( $p=0.105)(A)$ and galectin1 knockout $(p=0.614)(B)$ mice without irradiation. No role was found for endogenous galectin-1 in wild-type $(p=0.246)(C)$ and galectin-1 knockout $(p=0.560)(D)$ mice after irradiation. Green color represents galectin-1 knockdown cells.

were transplanted into wild-type and galectin-1 knockout mice. Radiation delayed the growth of tumors to $2 \mathrm{~cm}$ in size in both wild-type $(p=0.031)$ (Figure $2 \mathrm{~A})$ and galectin-1 knockout $(p=0.071)$ (Figure 2B) mice. The growth delay time is also less evident in galectin-1 knockout mice. In B16-F10 cells with galectin-1 knockdown, a difference in tumor growth was noted in both galectin-1 knockout $(p=0.001)$ (Figure 2C) and wild-type $(p=0.001)$ (Figure 2D) mice.

Effects of galectin-1 knockdown on tumor growth after irradiation. The effect of galectin-1 knockdown on tumor growth in LLC1 cells with or without irradiation was assessed, and no effect was found in wild-type mice $(p=0.105)$ (Figure 3A) or galectin-1 knockout mice $(p=0.614)$ (Figure 3B). Moreover, no effect was noted after irradiation (Figure 3C and D). The effect of galectin-1 knockdown in B16-F10 cells on tumor growth without irradiation was assessed, and no effect was found in wildtype mice $(p=0.770)$ (Figure 4A) or galectin-1 knockout mice $(p=0.678)$ (Figure 4B). However, in the case of radiation, although there was no difference in wild-type mice $(p=0.740)$ (Figure 4C), there was an almost significant difference in galectin-1 knockout mice $(p=0.052)$ (Figure $4 D$ ). The clonogenic assay showed no difference in the survival rate between wild-type and galectin-1 knockdown LCC1 (Figure 5A) or B16-F10 (Figure 5B) cells.

Effects of knockout mice on tumor growth after irradiation. The effect of knockout mice on the growth of wild-type LLC1 tumors without irradiation was assessed. T-cell knockout mice grew slowly $(p=0.005)$. However, B-cell knockout mice grew faster $(p<0.001)$. Galectin-1 knockout 
A

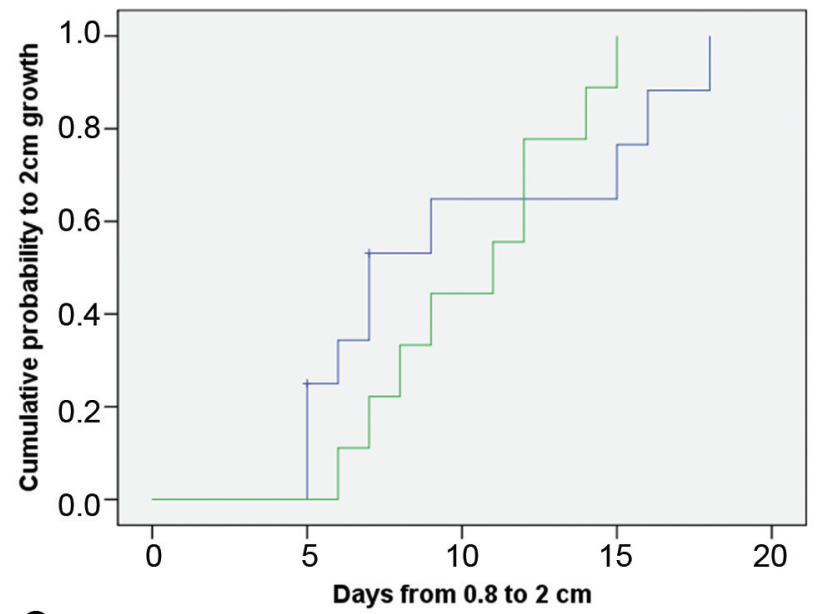

C

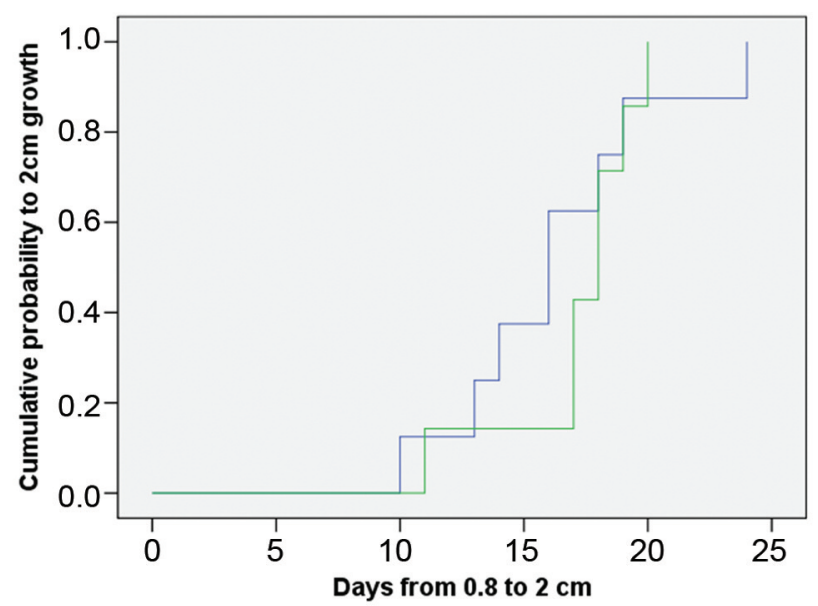

B

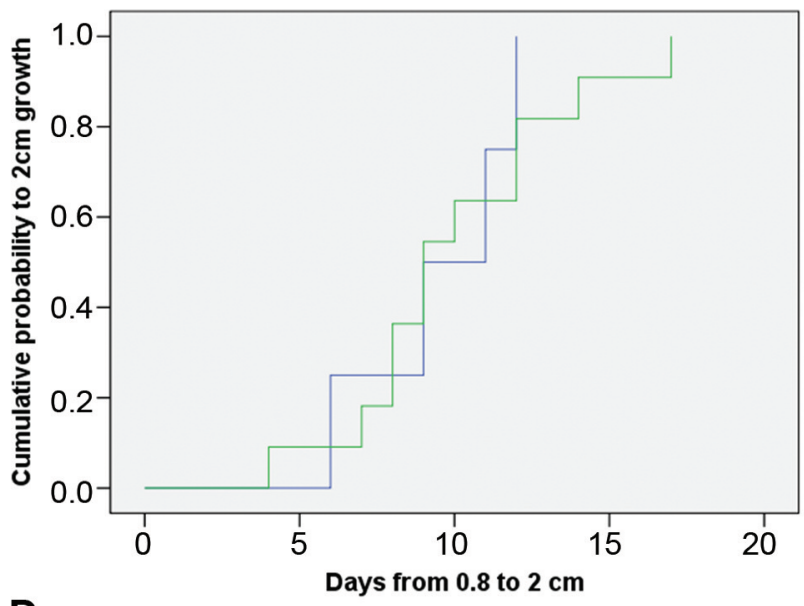

D

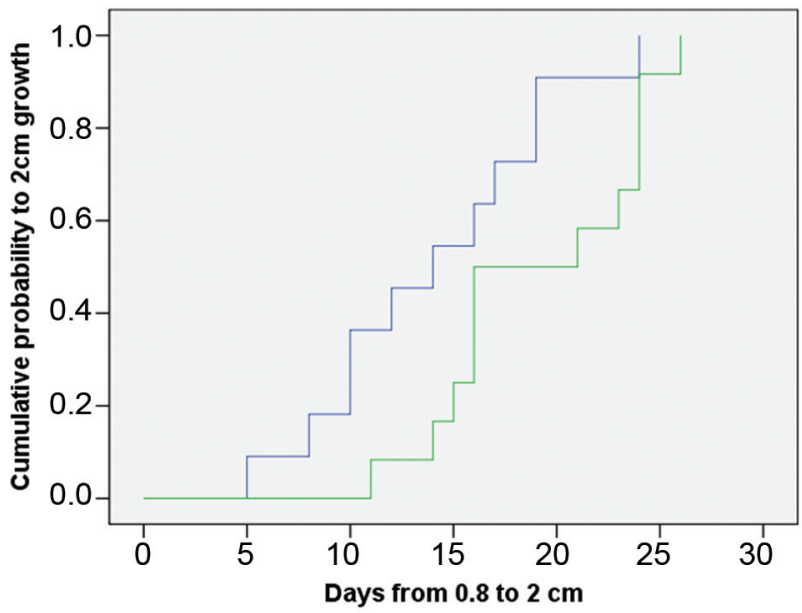

Figure 4. Effects of endogenous galectin-1 on B16-F10 tumor growth to $2 \mathrm{~cm}$. No role of endogenous galectin-1 in wild-type ( $p=0.770)$ (A) and galectin-1 knockout $(p=0.678)(B)$ mice without irradiation was observed. No role of endogenous galectin-1 in wild-type mice $(C)(p=0.740)$ after irradiation was noted. However, endogenous galectin-1 knockdown delayed tumor growth after irradiation in galectin-1 knockout (D) $(p=0.052)$ mice. Green color represents galectin-1 knockdown cells.

mice had no effect on tumor growth $(p=0.748)$ (Figure 6A). The effect of knockout mice on the growth of wild-type LLC1 tumors after irradiation was assessed, and it was found that T-cell knockout mice initially grew slowly but later grew quickly $(p=0.831)$. B-cell knockout mice grew faster $(p=0.013)$, and galectin-1 knockout mice also grew faster $(p=0.026)$ (Figure 6B). The effect of non-irradiated galectin1 knockdown LLC1 tumor growth was slightly affected $(p=0.070)$ (Figure 6C), and galectin-1 knockout mice grew faster. Tumor growth of galectin-1 knockdown LLC1 tumors had no effect on irradiation ( $p=0.252)$ (Figure 6D). Galectin1 knockout did not affect tumor growth in B16-F10 cells with wild-type $(p=0.742)$ (Figure 7A) or galectin-1 knockdown $(p=0.974)$ (Figure $7 \mathrm{~B})$ under no irradiation. Similarly, galectin-1 knockout in mice affected tumor growth with neither wild-type $(p=0.616)$ nor galectin- 1 knockdown $(p=0.193)$ (Figure 7C and D).

Effects of galectin-1 knockout mice on F4/80 expression. In LLC-1 cells implanted in wild-type mice, the expression of macrophage-specific antigen F4/80 was strong in both galectin-1 wild-type (Figure $8 \mathrm{~A}$ ) and galectin-1 knockdown (Figure 8B) cells. In LLC-1 cells implanted in galectin-1 knockout mice, F4/80 expression was weak in both galectin-1 wild-type (Figure 8C) and galectin-1 knockdown (Figure 8D) cells. In B16-F10 cells implanted in wild-type mice, the expression of F4/80 was strong in both galectin1 wild-type (Figure 9A) and galectin-1 knockdown (Figure 9B) cells. In B16-F10 cells implanted in galectin-1 knockout mice, F4/80 expression was weak in both 
A

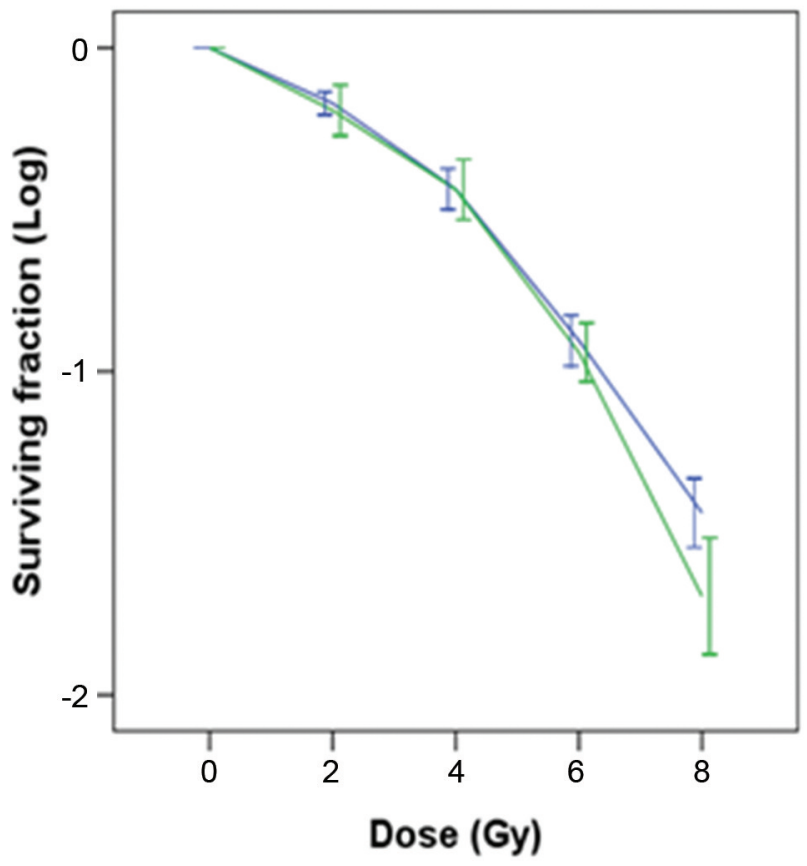

B

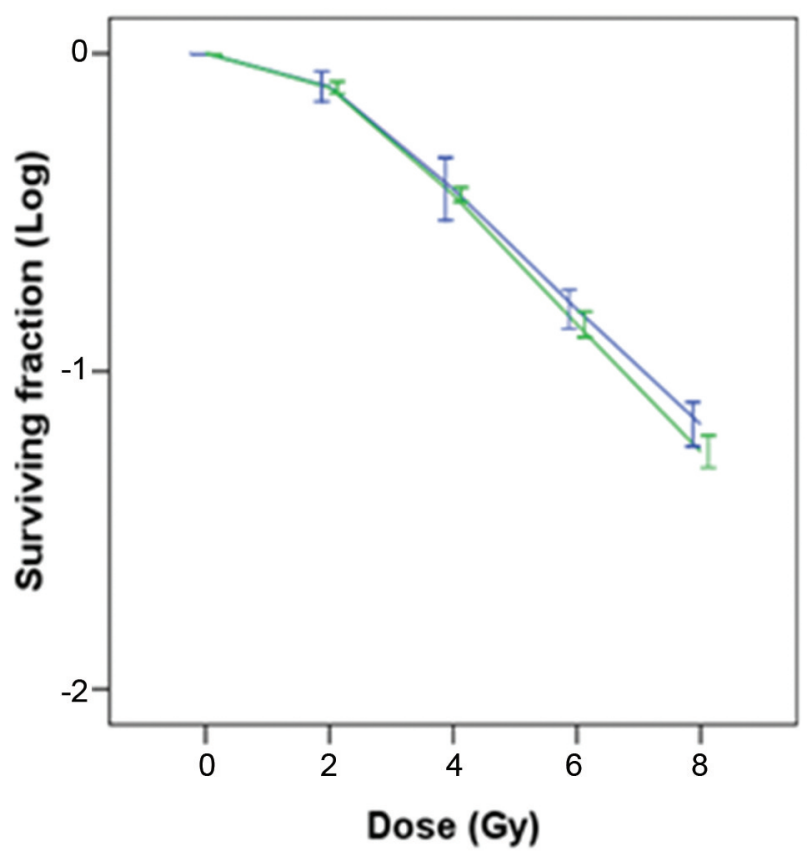

Figure 5. Effects of endogenous galectin-1 on clonogenic survival in LLC1 (A) and B16-F10 (B) cells. Green color represents galectin-1 knockdown cells.

galectin-1 wild-type (Figure 9C) and galectin-1 knockdown (Figure 9D) cells.

\section{Discussion}

This study used galectin-1, B cell, and T cell knockout mice to investigate the impact of the microenvironment. The main finding was that endogenous galectin-1 in B16F10 cells had a radioresistant effect in galectin-1 knockout mice. This phenomenon is not observed in LCC1 cells. Exogenous galectin-1 instead radiosensitized wild-type LLC1 cells. However, it is interesting to note that the clonogenic assay does not show that galectin-1 causes radioresistance, so whether the factor that mediates the effect is secreted outside of the cell remains to be explored. The observations in these two cells are not exactly the same. The differences are related to the differences in the immune microenvironment.

Based on the faster growth of B cell knockout mice, we can make the following inferences. Surprisingly, galectin-1 knockout mice grew tumors faster, and the only explanation was that extracellular galectin-1 inhibited tumor growth. The importance of B cells is observed in this setting. In fact, B cells also show galectin-1 expression $(14,15)$. Galectin-1 can induce B cell differentiation (16-18) and even promote the production of antibodies in plasma cells (19). CD20 ${ }^{+}$B cells are also more important in anticancer immunity (20). Tumorinfiltrating $\mathrm{B}$ cells regulate the ability of $\mathrm{T}$ cells to kill tumors (21). A lower ratio of tumor-infiltrating $\mathrm{CD} 10^{+}$ neutrophils/CD20 ${ }^{+}$lymphocytes is associated with a better prognosis (22). We found that B cell knockout mouse tumors grew faster, indicating that B cells can inhibit tumor growth and that extracellular galectin-1 can stimulate B cell differentiation. These results explain why galectin-1 or B cell knockout mouse tumor growth is faster.

We noted that F4/80 was expressed in all types of cancer cells in wild-type mice, but it was weaker in galectin-1 knockout mice. Almost no expression of F4/80 was noted in LLC1 cells but not B16-F10 cells. This finding may explain the different radiosensitivities of these two cell lines. Changes in the tumor microenvironment may affect the performance of macrophages. Van Woensel et al. found that the M2/M1 ratio of galectin-1 knockout mice was lower (23), and in our study CEA promoted M2 differentiation (24). Therefore, the regulation of galectin-1 indirectly affects cell anticancer immunity.

Galectin-1 not only achieves immunosuppressive effects through $\mathrm{T}$ cells but also attracts myeloid cells to tumors to produce immunosuppression. Galectin-1 causes radioresistance (10). Hypoxia will induce galectin-1 expression in tumors (10) and attract macrophages to hypoxic tumors $(12,13)$. Baker et al. also found that galectin-1 knockdown brain tumor cells have more NK cell aggregation than wild-type cancer cells (8). Therefore, it is very likely that tumor galectin-1 will not only inhibit anticancer $\mathrm{T}$ and $\mathrm{NK}$ cells around the tumor but also attract macrophages to the tumor. 
A

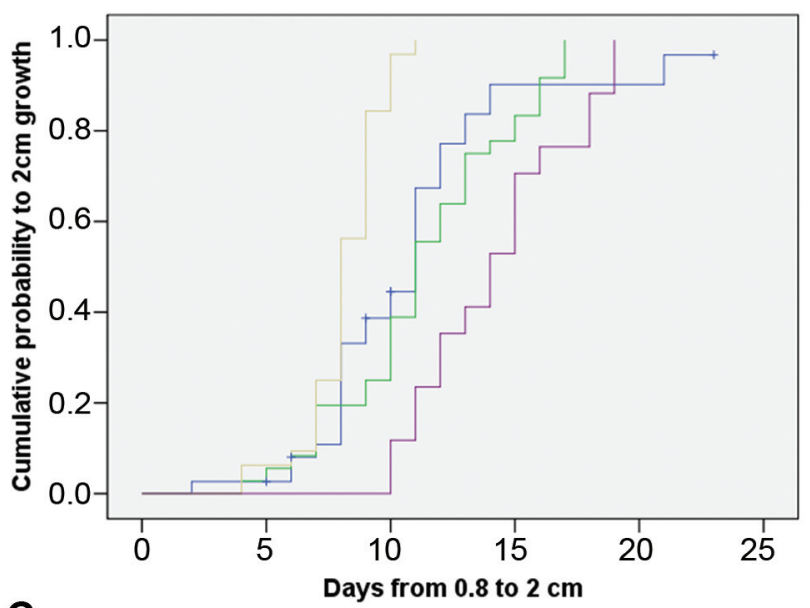

C

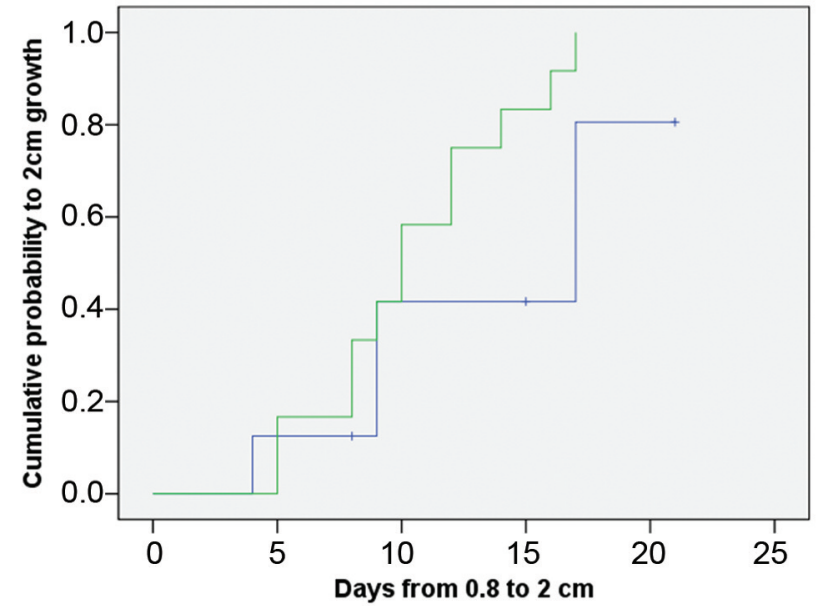

B

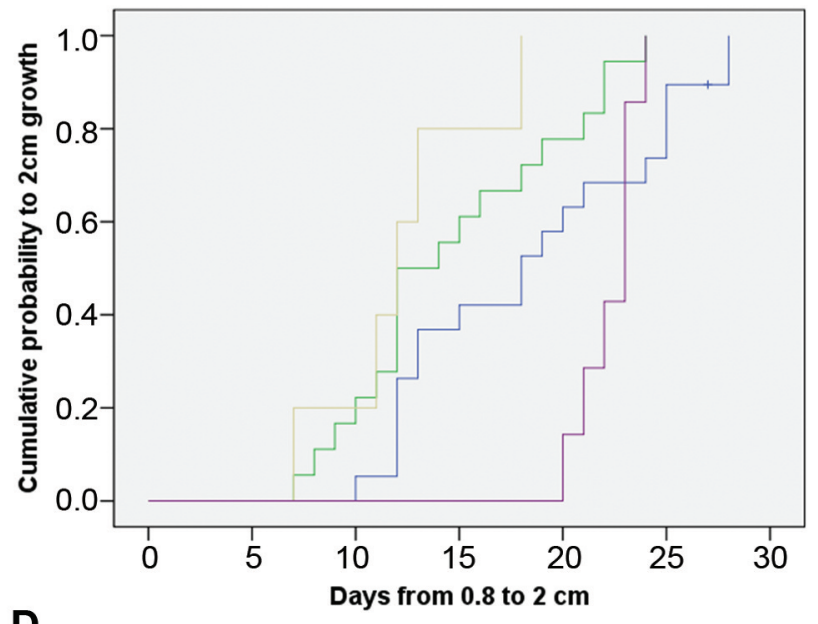

D

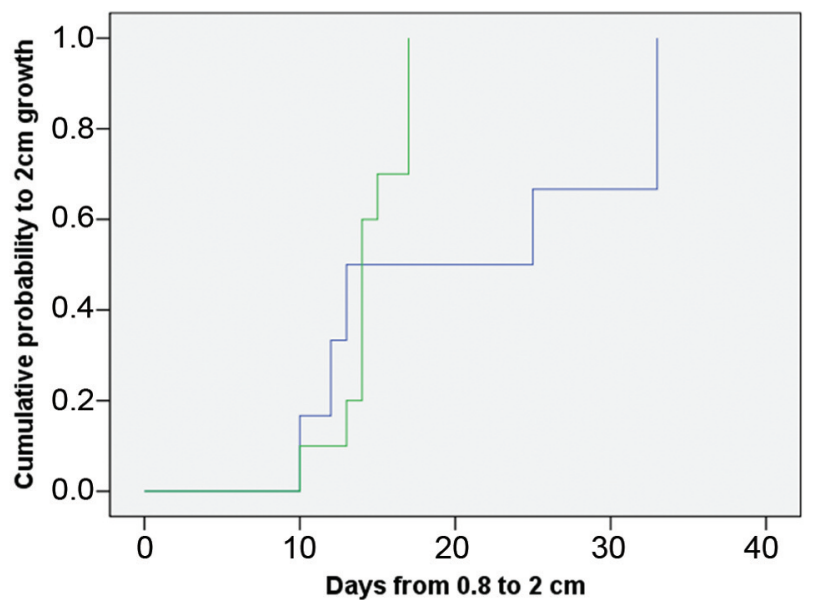

Figure 6. Effects of galectin-1 (green), B cell (yellow), and T cell (purple) knockout mice on LLC1 tumor growth to $2 \mathrm{~cm}$ in comparison to wildtype mice. Under non-irradiation conditions with wild-type cells (A), T-cell knockout mice grew slowly $(p=0.005)$. B-cell knockout mice grew faster $(p<0.001)$. Galectin-1 knockout mice experienced no effect ( $p=0.748)$. After irradiation of wild-type cells $(B)$, both B-cell ( $p=0.013)$ and galectin$1(p=0.026)$ but not T-cell $(p=0.831)$ knockout mice grew faster. Under non-irradiation conditions with galectin-1 knockdown cells $(C)$, no difference between wild-type and galectin-1 knockout mice was noted $(p=0.070)$. After irradiation of galectin-1 knockdown cells $(D)$, no difference was noted between wild-type and galectin-1 knockout mice $(p=0.252)$.

Therefore, if we can inhibit the conversion of M0 to M2 or M0/M2 to M1, tumor progression may be suppressed, and TAMs may secrete epidermal growth factor (EGF) and stimulate tumor progression (25). EGF activates EGFR and Ras and causes radiation resistance $(26,27)$. Macrophages are an indicator of poor prognosis in many tumors, including cancers we intend to study, such as renal cell carcinoma (28-30), melanoma (31, 32), lung cancer (13, $33,34)$, and prostate cancer $(11,35-37)$. Other galectins have similar effects on cancer progression and immune modulation. For example, galectin- 8 promotes angiogenesis (38) and cancer progression $(39,40)$. It collaborates with galectin-1 in promoting plasma cell formation (41). Galectin-1 and galectin- 8 bound better to mature B cells than plasma cells (41). In future studies it is worth investigating the interaction between galectins and immune cells.

In conclusion, endogenous galectin-1-mediated radioresistance exists in cases without extracellular galectin-1. Extracellular galectin-1 needs endogenous galectin-1 to radiosensitize tumors in mice. The role of $\mathrm{B}$ cells in enhancing radiosensitization is worthy of further investigation.

\section{Conflicts of Interest}

The Authors have no conflicts of interest. 
A

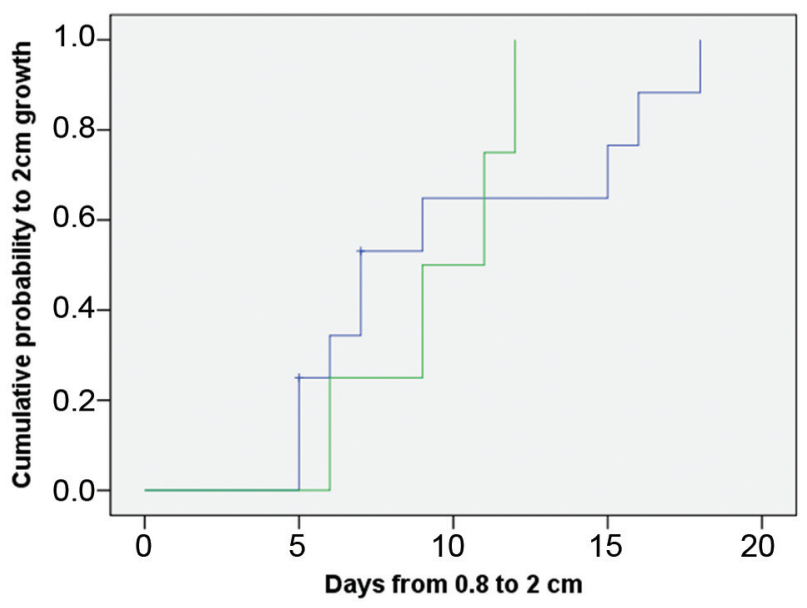

C

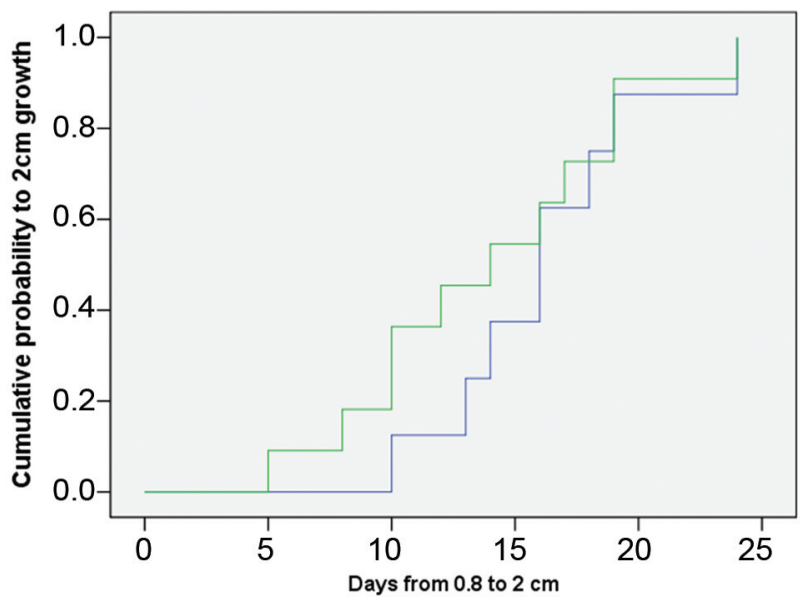

B

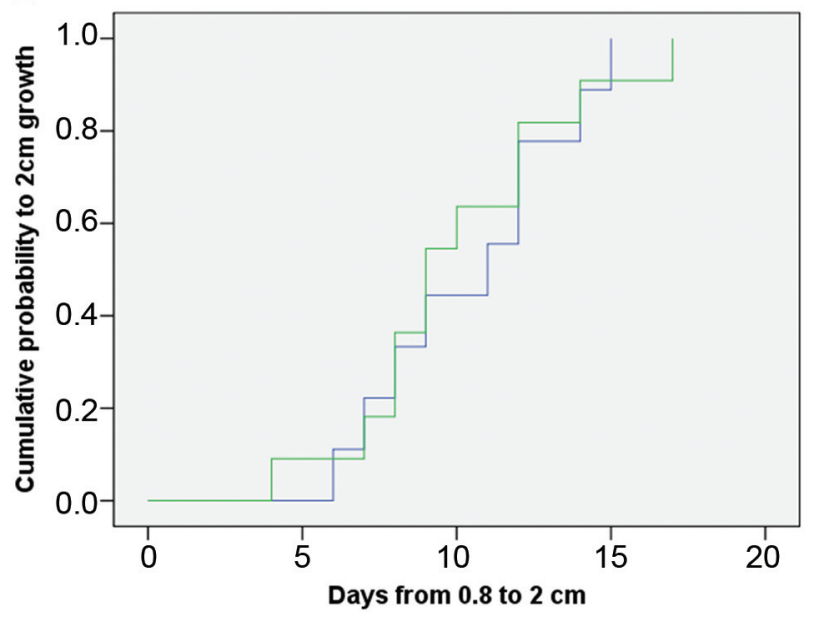

D

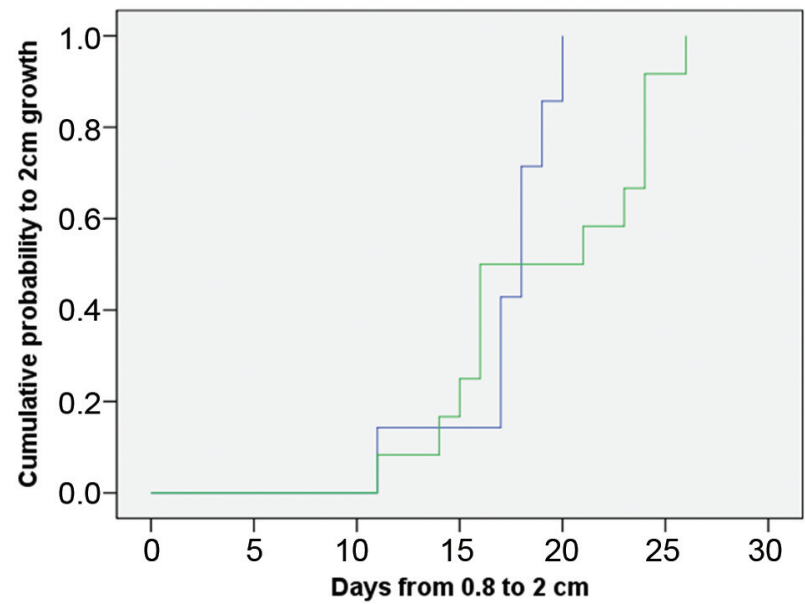

Figure 7. Effects of galectin-1 knockout mice on wild-type or galectin-1 knockdown B16-F10 tumor growth to $2 \mathrm{~cm}$. Under non-irradiation conditions with wild-type cells (A) and galectin-1 knockdown cells (B), no difference was noted between wild-type and galectin-1 knockout mice. Under 8 Gy irradiation conditions with wild-type cells $(C)$ and galectin-1 knockdown cells $(D)$, no difference was noted between wild-type and galectin-1 knockout mice.

\section{Authors' Contributions}

Conceptualization, E.-Y.H.; investigation, Y.-F. C., C.-C. W., C.-Y. H. and E.-Y.H.; methodology, Y.-F. C., C.-C. W. and C.-Y. H.; data curation, Y.-F. C., and C.-C. W.; formal analysis, E.-Y.H.; validation, E.-Y.H.; writing - original draft preparation, Y.-F. C., and C.-C. W.; writing - review and editing, Y.-F. C., C.-C. W., and E.-Y.H..; supervision, E.-Y.H.; project administration, Y.-F. C., C.-C. W. and C.-Y. H.; funding acquisition, E.-Y.H. All Authors have read and agreed to the published version of the manuscript.

\section{Acknowledgements}

This work was supported by Chang-Gung Medical Research Project (CMRPG8E0361-3).

\section{References}

1 Astorgues-Xerri L, Riveiro ME, Tijeras-Raballand A, Serova M, Neuzillet C, Albert S, Raymond E and Faivre S: Unraveling galectin-1 as a novel therapeutic target for cancer. Cancer Treat Rev 40(2): 307-319, 2014. PMID: 23953240. DOI: 10.1016/ j.ctrv.2013.07.007

2 Ito K, Stannard K, Gabutero E, Clark AM, Neo SY, Onturk S, Blanchard H and Ralph SJ: Galectin-1 as a potent target for cancer therapy: Role in the tumor microenvironment. Cancer Metastasis Rev 31(3-4): 763-778, 2012. PMID: 22706847. DOI: 10.1007/s10555-012-9388-2

3 Kuo P and Le QT: Galectin-1 links tumor hypoxia and radiotherapy. Glycobiology 24(10): 921-925, 2014. PMID: 24973253. DOI: $10.1093 /$ glycob/cwu062 
A

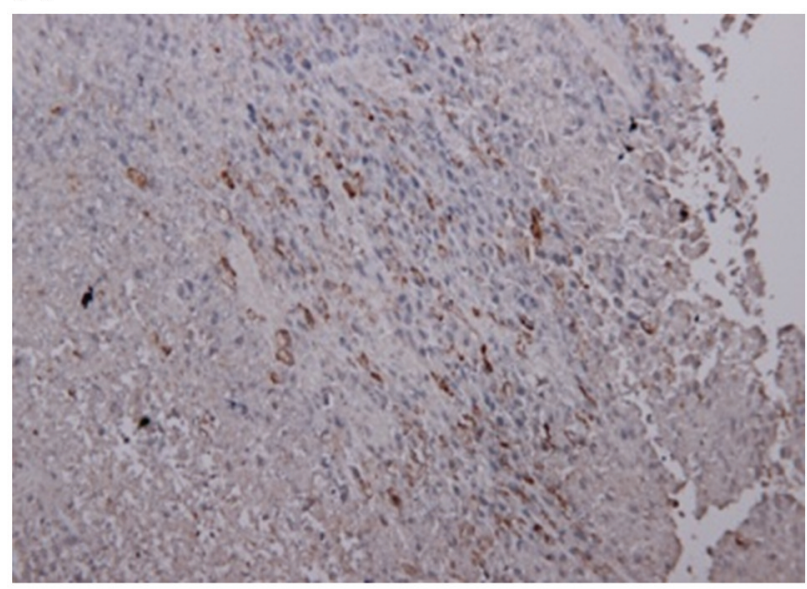

C

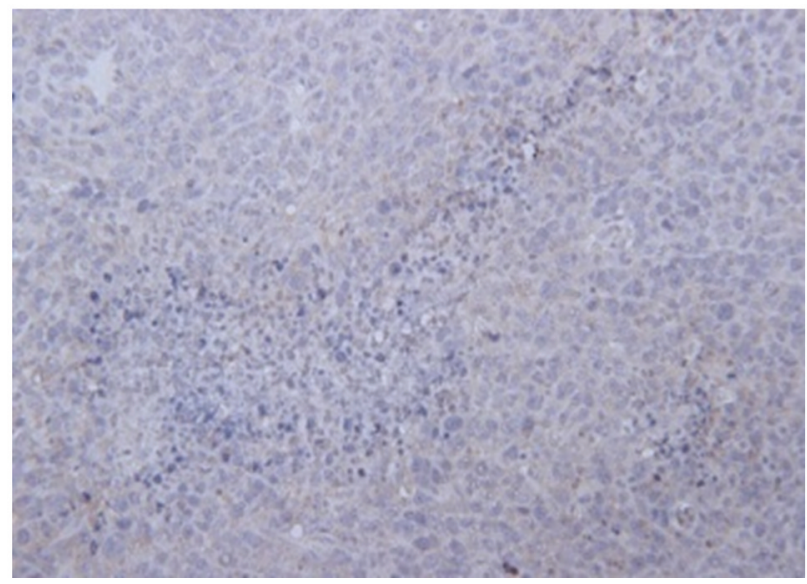

B

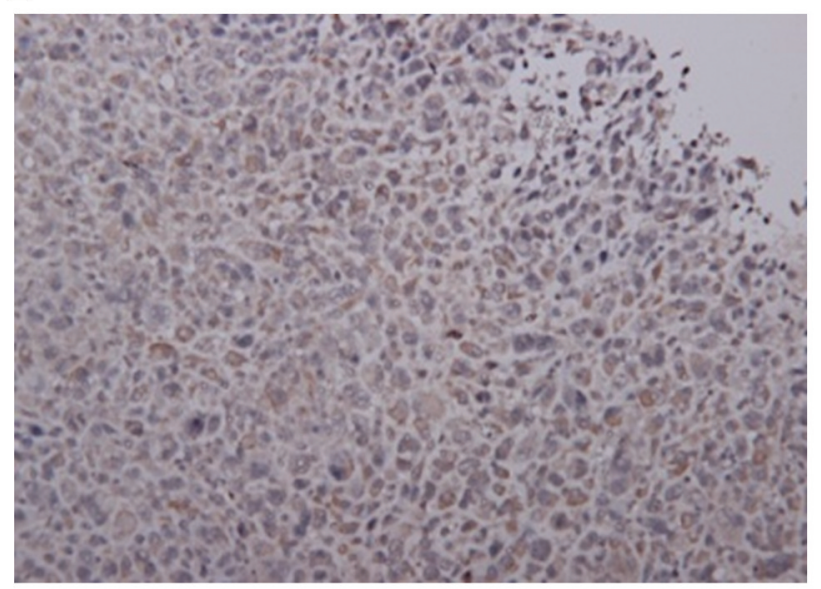

D

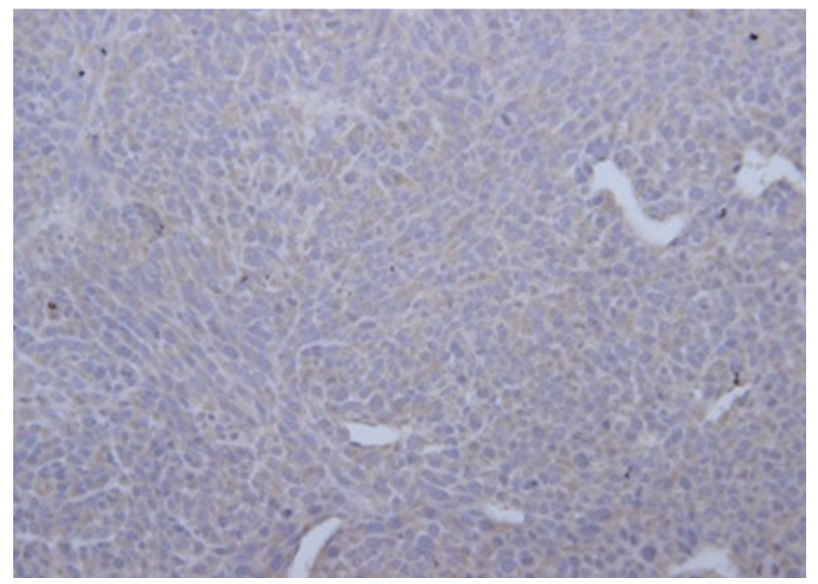

Figure 8. F4-80 expression in wild-type LLC1 tumors in wild-type mice (A), galectin-1 knockdown LLC1 tumors in wild-type mice (B), wild-type LLC1 tumors in galectin-1 knockout mice (C), and galectin-1 knockdown LLC1 tumors in galectin-1 knockout mice (D).

4 Huang EY, Chen YF, Chen YM, Lin IH, Wang CC, Su WH, Chuang PC and Yang KD: A novel radioresistant mechanism of galectin-1 mediated by H-Ras-dependent pathways in cervical cancer cells. Cell Death Dis 3: e251, 2012. PMID: 22237208. DOI: $10.1038 /$ cddis.2011.120

5 Huang EY, Chanchien CC, Lin H, Wang CC, Wang CJ and Huang CC: Galectin-1 is an independent prognostic factor for local recurrence and survival after definitive radiation therapy for patients with squamous cell carcinoma of the uterine cervix. Int J Radiat Oncol Biol Phys 87(5): 975-982, 2013. PMID: 24139517. DOI: $10.1016 /$ j.ijrobp.2013.08.037

6 Mobergslien A and Sioud M: Galectin-1 and -3 gene silencing in immature and mature dendritic cells enhances $\mathrm{T}$ cell activation and interferon- $\gamma$ production. J Leukoc Biol 91(3): 461-467, 2012. PMID: 22167721. DOI: 10.1189/jlb.0711361

7 Kuo P, Bratman SV, Shultz DB, von Eyben R, Chan C, Wang Z, Say C, Gupta A, Loo BW Jr, Giaccia AJ, Koong AC, Diehn M and Le QT: Galectin-1 mediates radiation-related lymphopenia and attenuates NSCLC radiation response. Clin Cancer Res 20(21): 5558-5569, 2014. PMID: 25189484. DOI: 10.1158/ 1078-0432.CCR-14-1138
8 Baker GJ, Chockley P, Yadav VN, Doherty R, Ritt M, Sivaramakrishnan S, Castro MG and Lowenstein PR: Natural killer cells eradicate galectin-1-deficient glioma in the absence of adaptive immunity. Cancer Res 74(18): 5079-5090, 2014. PMID: 25038230. DOI: 10.1158/0008-5472.CAN-14-1203

9 Garín MI, Chu CC, Golshayan D, Cernuda-Morollón E, Wait R and Lechler RI: Galectin-1: A key effector of regulation mediated by CD4+CD25+ T cells. Blood 109(5): 2058-2065, 2007. PMID: 17110462. DOI: 10.1182/blood-2006-04-016451

10 Le QT, Shi G, Cao H, Nelson DW, Wang Y, Chen EY, Zhao S, Kong C, Richardson D, O'Byrne KJ, Giaccia AJ and Koong AC: Galectin-1: A link between tumor hypoxia and tumor immune privilege. J Clin Oncol 23(35): 8932-8941, 2005. PMID: 16219933. DOI: $10.1200 / J C O .2005 .02 .0206$

11 Chen FH, Chiang CS, Wang CC, Tsai CS, Jung SM, Lee CC, McBride WH and Hong JH: Radiotherapy decreases vascular density and causes hypoxia with macrophage aggregation in TRAMP-C1 prostate tumors. Clin Cancer Res 15(5): 1721-1729, 2009. PMID: 19240176. DOI: 10.1158/1078-0432.CCR-08-1471

$12 \mathrm{Kim}$ R, Emi M and Tanabe K: Cancer cell immune escape and tumor progression by exploitation of anti-inflammatory and pro- 
A

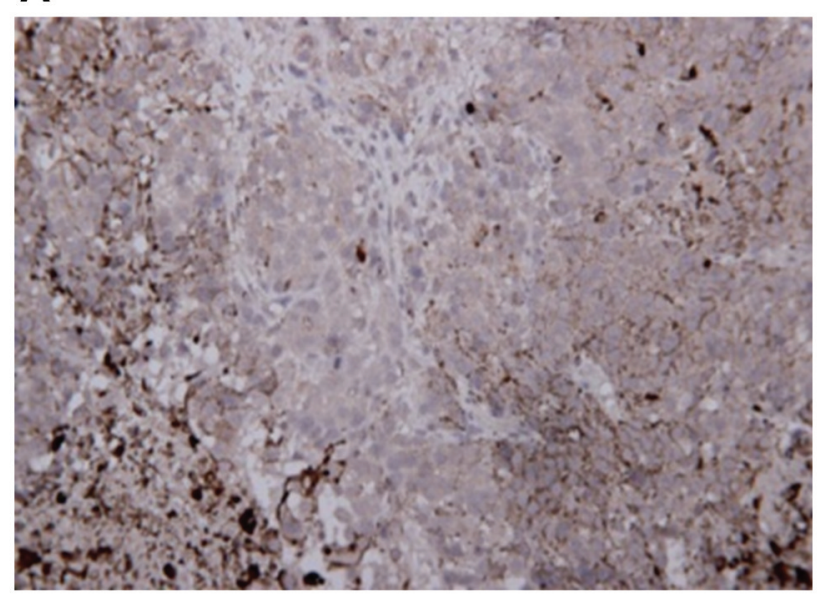

C

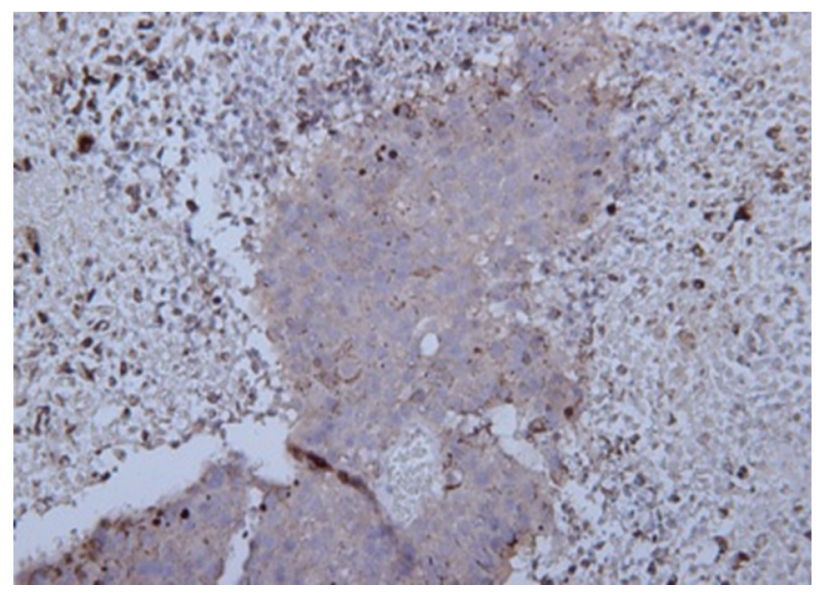

B

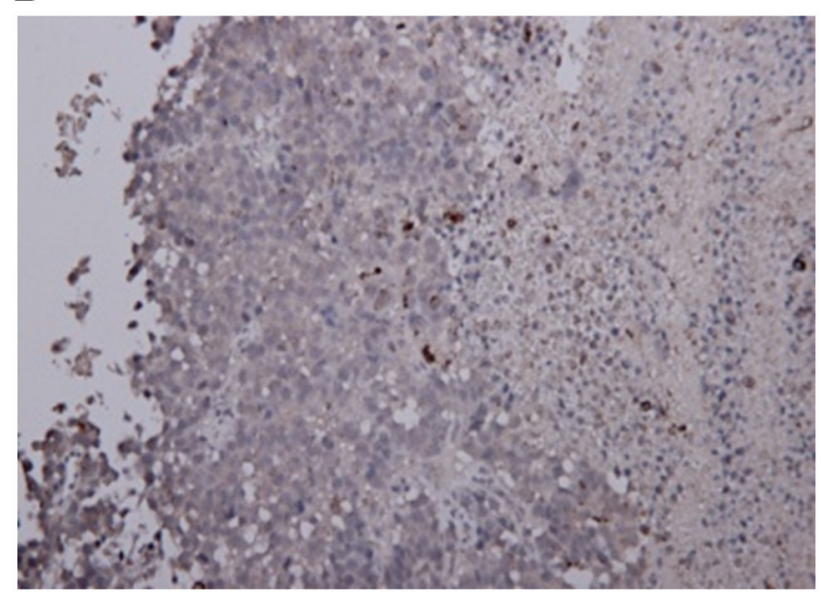

D

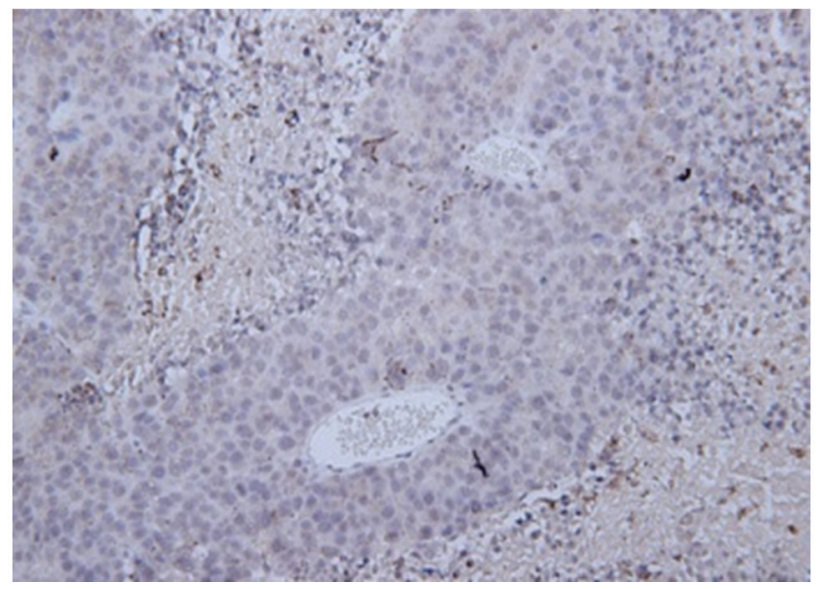

Figure 9. F4-80 expression in wild-type B16-F10 tumors in wild-type mice (A), galectin-1 knockdown B16-F10 tumors in wild-type mice (B), wildtype B16-F10 tumors in galectin-1 knockout mice (C), and galectin-1 knockdown B16-F10 tumors in galectin-1 knockout mice.

inflammatory responses. Cancer Biol Ther 4(9): 924-933, 2005. PMID: 16177562. DOI: 10.4161/cbt.4.9.2101

13 Zhang J, Cao J, Ma S, Dong R, Meng W, Ying M, Weng Q, Chen Z, Ma J, Fang Q, He Q and Yang B: Tumor hypoxia enhances non-small cell lung cancer metastasis by selectively promoting macrophage M2 polarization through the activation of ERK signaling. Oncotarget 5(20): 9664-9677, 2014. PMID: 25313135. DOI: $10.18632 /$ oncotarget.1856

14 Zuñiga E, Rabinovich GA, Iglesias MM and Gruppi A: Regulated expression of galectin-1 during B-cell activation and implications for T-cell apoptosis. J Leukoc Biol 70(1): 73-79, 2001. PMID: 11435488

15 Alhabbab R, Blair P, Smyth LA, Ratnasothy K, Peng Q, Moreau A, Lechler R, Elgueta R and Lombardi G: Galectin-1 is required for the regulatory function of B cells. Sci Rep 8(1): 2725, 2018. PMID: 29426942. DOI: 10.1038/s41598-018-19965-z

16 Mourcin F, Breton C, Tellier J, Narang P, Chasson L, Jorquera A, Coles M, Schiff C and Mancini SJ: Galectin-1-expressing stromal cells constitute a specific niche for pre-BII cell development in mouse bone marrow. Blood 117(24): 6552-6561, 2011. PMID: 21511956. DOI: $10.1182 /$ blood-2010-12-323113
17 Espeli M, Mancini SJ, Breton C, Poirier F and Schiff C: Impaired B-cell development at the pre-BII-cell stage in galectin-1-deficient mice due to inefficient pre-BII/stromal cell interactions. Blood 113(23): 5878-5886, 2009. PMID: 19329777. DOI: 10.1182/blood2009-01-198465

18 Bonzi J, Bornet O, Betzi S, Kasper BT, Mahal LK, Mancini SJ, Schiff C, Sebban-Kreuzer C, Guerlesquin F and Elantak L: Pre-B cell receptor binding to galectin-1 modifies galectin-1/carbohydrate affinity to modulate specific galectin-1/glycan lattice interactions. Nat Commun 6: 6194, 2015. PMID: 25708191. DOI:10.1038/ncomms7194

19 Tsai CM, Chiu YK, Hsu TL, Lin IY, Hsieh SL and Lin KI: Galectin-1 promotes immunoglobulin production during plasma cell differentiation. J Immunol 181(7): 4570-4579, 2008. PMID: 18802059. DOI: $10.4049 /$ jimmunol.181.7.4570

20 Bodogai M, Lee Chang C, Wejksza K, Lai J, Merino M, Wersto RP, Gress RE, Chan AC, Hesdorffer C and Biragyn A: AntiCD20 antibody promotes cancer escape via enrichment of tumor-evoked regulatory B cells expressing low levels of CD20 and CD137L. Cancer Res 73(7): 2127-2138, 2013. PMID: 23365136. DOI: 10.1158/0008-5472.CAN-12-4184 
21 Bruno TC, Ebner PJ, Moore BL, Squalls OG, Waugh KA, Eruslanov EB, Singhal S, Mitchell JD, Franklin WA, Merrick DT, McCarter MD, Palmer BE, Kern JA and Slansky JE: Antigen-presenting intratumoral B cells affect CD4+ TIL phenotypes in non-small cell lung cancer patients. Cancer Immunol Res 5(10): 898-907, 2017. PMID: 28848053. DOI: 10.1158/2326-6066.CIR-17-0075

22 Kadota K, Nitadori JI, Ujiie H, Buitrago DH, Woo KM, Sima CS, Travis WD, Jones DR and Adusumilli PS: Prognostic impact of immune microenvironment in lung squamous cell carcinoma: Tumor-infiltrating CD10+ neutrophil/CD20+ lymphocyte ratio as an independent prognostic factor. J Thorac Oncol 10(9): 1301-1310, 2015. PMID: 26291010. DOI: 10.1097/JTO.0000000000000617

23 Van Woensel M, Mathivet T, Wauthoz N, Rosière R, Garg AD, Agostinis P, Mathieu V, Kiss R, Lefranc F, Boon L, Belmans J, Van Gool SW, Gerhardt H, Amighi K and De Vleeschouwer S: Sensitization of glioblastoma tumor micro-environment to chemo- and immunotherapy by Galectin-1 intranasal knockdown strategy. Sci Rep 7(1): 1217, 2017. PMID: 28450700. DOI: 10.1038/s41598-017-01279-1

24 Huang EY, Chang JC, Chen HH, Hsu CY, Hsu HC and Wu KL: Carcinoembryonic antigen as a marker of radioresistance in colorectal cancer: A potential role of macrophages. BMC Cancer 18(1): 321, 2018. PMID: 29580202. DOI: 10.1186/s12885-0184254-4

25 Laoui D, Movahedi K, Van Overmeire E, Van den Bossche J, Schouppe E, Mommer C, Nikolaou A, Morias Y, De Baetselier P and Van Ginderachter JA: Tumor-associated macrophages in breast cancer: Distinct subsets, distinct functions. Int J Dev Biol 55(7-9): 861-867, 2011. PMID: 22161841. DOI: 10.1387/ijdb.113371dl

26 Chakravarti A, Chakladar A, Delaney MA, Latham DE and Loeffler JS: The epidermal growth factor receptor pathway mediates resistance to sequential administration of radiation and chemotherapy in primary human glioblastoma cells in a RAS-dependent manner. Cancer Res 62(15): 4307-4315, 2002. PMID: 12154034.

27 Toulany M, Dittmann K, Baumann M and Rodemann HP: Radiosensitization of Ras-mutated human tumor cells in vitro by the specific EGF receptor antagonist BIBX1382BS. Radiother Oncol 74(2): 117-129, 2005. PMID: 15734199. DOI: 10.1016/j.radonc.2004.11.008

$28 \mathrm{Li} \mathrm{C}$, Liu B, Dai Z and Tao Y: Knockdown of VEGF receptor-1 (VEGFR-1) impairs macrophage infiltration, angiogenesis and growth of clear cell renal cell carcinoma (CRCC). Cancer Biol Ther 12(10): 872-880, 2011. PMID: 21989163. DOI: $10.4161 /$ cbt.12.10.17672

29 Komohara Y, Hasita H, Ohnishi K, Fujiwara Y, Suzu S, Eto M and Takeya M: Macrophage infiltration and its prognostic relevance in clear cell renal cell carcinoma. Cancer Sci 102(7): 1424-1431, 2011. PMID: 21453387. DOI: 10.1111/j.1349-7006.2011.01945.x

30 Su B, Zhao W, Shi B, Zhang Z, Yu X, Xie F, Guo Z, Zhang X, Liu J, Shen Q, Wang J, Li X, Zhang Z and Zhou L: Let-7d suppresses growth, metastasis, and tumor macrophage infiltration in renal cell carcinoma by targeting COL3A1 and CCL7. Mol Cancer 13: 206, 2014. PMID: 25193015. DOI: 10.1186/1476-4598-13-206

31 Jensen TO, Schmidt H, Møller HJ, Høyer M, Maniecki MB, Sjoegren P, Christensen IJ and Steiniche T: Macrophage markers in serum and tumor have prognostic impact in American joint committee on cancer stage I/II melanoma. J Clin Oncol 27(20): 3330-3337, 2009. PMID: 19528371. DOI: 10.1200/JCO.2008. 19.9919
32 Tham M, Khoo K, Yeo KP, Kato M, Prevost-Blondel A, Angeli $\mathrm{V}$ and Abastado JP: Macrophage depletion reduces postsurgical tumor recurrence and metastatic growth in a spontaneous murine model of melanoma. Oncotarget 6(26): 22857-22868, 2015. PMID: 25762633. DOI: 10.18632/oncotarget.3127

33 Wang R, Lu M, Zhang J, Chen S, Luo X, Qin Y and Chen H: Increased IL-10 mRNA expression in tumor-associated macrophage correlated with late stage of lung cancer. J Exp Clin Cancer Res 30: 62, 2011. PMID: 21595995. DOI: 10.1186/17569966-30-62

34 Li Q, Liu L, Zhang Q, Liu S, Ge D and You Z: Interleukin-17 indirectly promotes M2 macrophage differentiation through stimulation of COX-2/PGE2 pathway in the cancer cells. Cancer Research and Treatment 46(3): 297-306, 2019. DOI: 10.4143/crt.2014.46.3.297

35 Gollapudi K, Galet C, Grogan T, Zhang H, Said JW, Huang J, Elashoff D, Freedland SJ, Rettig $\mathrm{M}$ and Aronson WJ: Association between tumor-associated macrophage infiltration, high grade prostate cancer, and biochemical recurrence after radical prostatectomy. Am J Cancer Res 3(5): 523-529, 2013. PMID: 24224130.

36 Chen PC, Cheng HC, Wang J, Wang SW, Tai HC, Lin CW and Tang CH: Prostate cancer-derived $\mathrm{CCN} 3$ induces M2 macrophage infiltration and contributes to angiogenesis in prostate cancer microenvironment. Oncotarget 5(6): 1595-1608, 2014. PMID: 24721786. DOI: 10.18632/oncotarget.1570

37 Escamilla J, Schokrpur S, Liu C, Priceman SJ, Moughon D, Jiang Z, Pouliot F, Magyar C, Sung JL, Xu J, Deng G, West BL, Bollag G, Fradet Y, Lacombe L, Jung ME, Huang J and Wu L: CSF1 receptor targeting in prostate cancer reverses macrophagemediated resistance to androgen blockade therapy. Cancer Res 75(6): 950-962, 2015. PMID: 25736687. DOI: 10.1158/00085472.CAN-14-0992

38 Varinská L, Fáber L, Petrovová E, Balážová L, Ivančová E, Kolář M and Gál P: Galectin-8 Favors VEGF-Induced Angiogenesis: In vitro study in human umbilical vein endothelial cells and in vivo study in chick chorioallantoic membrane. Anticancer Res 40(6): 3191-3201, 2020. PMID: 32487613. DOI: 10.21873/anticanres.14300

39 Carlsson MC, Balog CI, Kilsgård O, Hellmark T, Bakoush O, Segelmark M, Fernö M, Olsson H, Malmström J, Wuhrer M and Leffler H: Different fractions of human serum glycoproteins bind galectin-1 or galectin-8, and their ratio may provide a refined biomarker for pathophysiological conditions in cancer and inflammatory disease. Biochim Biophys Acta 1820(9): 1366-1372, 2012. PMID: 22285770. DOI: 10.1016/j.bbagen.2012.01.007

40 Cludts S, Decaestecker C, Mahillon V, Chevalier D, Kaltner H, André S, Remmelink M, Leroy X, Gabius HJ and Saussez S: Galectin-8 up-regulation during hypopharyngeal and laryngeal tumor progression and comparison with galectin-1, -3 and -7 . Anticancer Res 29(12): 4933-4940, 2009. PMID: 20044599.

41 Tsai CM, Guan CH, Hsieh HW, Hsu TL, Tu Z, Wu KJ, Lin CH and Lin KI: Galectin-1 and galectin- 8 have redundant roles in promoting plasma cell formation. J Immunol 187(4): 1643-1652, 2011. PMID: 21753146. DOI: 10.4049/jimmunol.1100297

Received February 2, 2021

Revised March 10, 2021

Accepted March 22, 2021 